\title{
KILKA UWAG O ZAGRANICZNEJ PODRÓŻY EDUKACYJNEJ MŁODYCH TARŁÓW (1663)*
}

\author{
Anna Markiewicz \\ Uniwersytet Jagielloński w Krakowie
}

\begin{abstract}
SOME REMARKS ON THE GRAND TOUR OF THE YOUNG TARŁOS

(1663)
\end{abstract}

In the second half of the $17^{\text {th }}$ century, the educational journey, the grand tour, constituted the last stage of education of the European elites. To travel abroad was also important for young noblemen and aristocrats from the Polish-Lithuanian Commonwealth, and the grand tour became an established part of the educational canon of the period. It was also considered the key to a future career and successful participation in court and public life. Autograph books (alba amicorum) are a valuable source for discovering and reconstructing the course of an educational journey. The rich collection of the British Library in London holds an extremely interesting autograph book of a nobleman, probably of German origin, residing in Florence in the 1660s (Add MS 4976). Among over eighty entries, the album includes 3 names of Polish contributors, namely young Adam, Karol and Aleksander Tarło. The album is a valuable source that provides important details of the journey undertaken by the young Polish noblemen and insights into the contacts and routes of their grand tour.

Key words: educational journey, grand tour, autograph book, Florence.

Słowa kluczowe: podróż edukacyjna, grand tour, sztambuch, Florencja.

W drugiej połowie XVII wieku zagraniczna podróż edukacyjna, grand tour, stanowiła ważny element wykształcenia młodych elit całej Europy ${ }^{1}$. Studia nad

${ }^{*}$ Artykuł powstał w ramach badań przeprowadzonych dzięki stypendium Fundacji z Brzezia Lanckorońskich na $2016 \mathrm{r}$.

1 Literatura poświęcona fenomenowi grand tour jest bardzo obszerna, zob.: J. Black, The British Abroad. The Grand Tour in the Eighteenth Century, London 2003; idem, Italy and the Grand Tour, New Haven-London 2003; idem, France and the Grand Tour, New York 2003; Ch. Hibbert, The Grand Tour, London 1969; W.E. Mead, The Grand Tour in the Eighteenth Century, Boston 1914; L.G. Trease, 
podróżami podejmowanymi przez mieszkańców Rzeczypospolitej, również wyjazdami o charakterze edukacyjnym, przeżywają w ostatnich latach swój rozkwit, a badacze zajmujący się historią kultury, życia codziennego, edukacji czy staropolskiej mentalności wielokrotnie podkreślali już rolę peregrynacji $\mathrm{w}$ epoce baroku². Dla młodej szlachty i magnaterii z ziem Rzeczypospolitej Obojga Narodów zagraniczny wyjazd edukacyjny był zarazem kwestią wyśmiewanej przez twórców fraszek mody, jak i życiową koniecznościąa . Wyjazd do „cudzych krajów” wieńczył wówczas cały proces edukacji, a sama podróż przygotowywała do dalszej kariery i życia publicznego. Poznanie krajów Europy Zachodniej stawało się powoli warunkiem awansu w karierze urzędniczej i politycznej, a wyprawienie młodego szlachcica do Paryża i Rzymu poświadczało prestiż rodziny. W odbywanych w drugiej połowie XVII stulecia podróżach równie ważne jak lekcje w najlepszych akademiach stawało się samo poznanie świata. Młodzieniec wyruszał poza granice Rzeczypospolitej, aby jak pisano - „krajom, ludziom obcym przypatrzył i ich obyczajom”4. Wielką wagę przywiązywano również do nawiązywania stosownych dla swojego stanu kontaktów towarzyskich i obracania się w odpowiednich kręgach europejskich szlachty. W latach 80. XVII wieku hetman Stanisław Jabłonowski zwrócił się do wyruszających

The Grand Tour, London 1967; E. Chaney, The Evolution of the Grand Tour: Anglo-Italian Cultural Relations since the Renaissance, London 2002; idem, The Grand Tour and the Great Rebellion: Richard Lassels and "The Voyage of Italy" in the 17 Century, Geneve 1985; J. Boutier, Le Grand Tour des gentilshommes et les académies d'éducation pour la noblesse : France et Italie, XVI ${ }^{e}-X V I I I^{e}$ siècle [w:] Grand Tour. Adeliges Reisen und Europaische Kultur vom 14. bis 18. Jahrhundert. Akten der Internationalen Kolloquien in der villa Vigoni 1999 und im Deutschen Historischen Institut Paris 2000, hrsg. von R. Babel, W. Paravicini, Ostfildern 2005, s. 237-253; M. Leibetseder, Die Kavalierstour. Adlige Erziehungreisen im 17. und 18. Jahrhundert, Köln 2004; E. Chaney, T. Wilks, The Jacobean Grand Tour. Early Stuart Travellers in Europe, London-New York 2014; The Origins of the Grand Tour. The Travels of Robert Montagu, Lord Mandeville (1649-1654), William Hammond (1655-1658), and Banaster Maynard (1660-1663), ed. M.G. Brennan, London 2004.

2 O zagranicznych podróżach edukacyjnych z ziem Rzeczypospolitej Obojga Narodów zob. m.in.: A. Mączak, Życie codzienne w podróżach po Europie w XVI i XVII wieku, Warszawa 1980; Z. Pietrzyk, W kregu Strasburga. Z peregrynacji młodzieży z Rzeczpospolitej polsko-litewskiej w latach 15381621, Kraków 1997; J. Frejlichówna, Ideat wychowawczy szlachty polskiej w XVI i poczatku XVII wieku, Warszawa 1938; W. Czapliński, J. Długosz, Podróż młodego magnata do szkót, Warszawa 1969; H. Barycz, Z dziejów polskich wędrówek naukowych za granicę, Wrocław 1969; M. Bratun, „Ten wykwintny, wyksztatcony Europejczyk”. Zagraniczne studia i podróże edukacyjne Michała Jerzego Wandalina Mniszcha w latach 1762-1768, Opole 2002; M. Chachaj, Zagraniczna edukacja Radziwittów od poczatku XVI do połowy XVII wieku, Lublin 1995; M. Pawlak, Studia uniwersyteckie mtodzieży z Prus Królewskich w XVI-XVIII wieku, Torun 1988; D. Żołądź-Strzelczyk, Peregrinatio academica. Studia młodzieży polskiej z Korony $i$ Litwy na akademiach $i$ uniwersytetach niemieckich $w$ XVI i pierwszej potowie XVII wieku, Poznań 1996; W. Tygielski, Na cóż te koszta i trudy? W jakim celu w XVII wieku wysytano młodzież szlachecka na zagraniczne studia?, „Odrodzenie i Reformacja w Polsce” 2006, t. 50, s. 141-156; K. Targosz, Jana Sobieskiego nauki i peregrynacje, Wrocław 1985; M. Kamecka, Do cudzych krajów. Edukacyjne podróże szlachty polskiej do Francji w epoce saskiej, Białystok 2012; A. Kucharski, Theatrum peregrinandi. Poznawcze aspekty staropolskich podróży w epoce późnego baroku, Toruń 2013; B. Popiołek, Podróże edukacyjne i poznawcze w źródłach czasów saskich [w:] Polski Grand Tour w XVIII i początkach XIX wieku, red. A. Roćko, Warszawa 2014, s. 45-64.

3 S. Kot, Historia wychowania, t. I, Warszawa 1994, s. 247.

4 W. Potocki, Ogród fraszek, t. I, wyd. A. Brückner, Lwów 1907, s. 530. 
w podróż edukacyjną po Europie synów - Jana Stanisława i Aleksandra Jana - następująco: „Zalecam jednak i serio conversationes honestas z ludźmi urodzenia zacnego, z ludźmi na urzędach wielkich zostającemi, z ludźmi uczonemi i sławnemi cuiuscunque conditionis"s. Podobnie postępowali inni rodzice.

Rekonstrukcję pełnego obrazu zagranicznej podróży edukacyjnej młodego szlachcica z drugiej połowy XVII wieku umożliwiają różnorodne źródła. Należy tu wspomnieć: spisywane jeszcze $\mathrm{w}$ domu rodzinnym instrukcje dotyczące edukacji i szkicujące planowany przebieg podróży, pisane już na bieżąco podczas pobytu na zachodzie Europy diariusze i wszelkiego rodzaju notatki podróżne czy redagowane już nierzadko już po wielu latach po powrocie do Rzeczypospolitej pamiętniki oraz obszerną korespondencję prowadzoną między rodzicami, młodym podróżnikiem i jego guwernerem. Cenne są również źródła umożliwiające odtworzenie realiów finansowych danej podróży, takie jak rachunki czy spisy długów. Każdy typ źródeł pozwala na zarysowanie innego aspektu zagranicznej wyprawy, ale wszystkie pochodzące z nich informacje budują interesujący, barwny obraz XVII-wiecznych podróży.

Wyliczając materiały źródłowe związane z zagranicznymi peregrynacjami odbywanymi w okresie baroku, zapomina się czasem o XVII-wiecznych sztambuchach. Tymczasem sztambuch, określany między innymi jako: liber amicorum, album amicorum, liber memorabilis, thesaurus amicorum, philoteca czy - w języku polskim - „imionnik”, to cenne źródło do badań nad staropolskimi peregrynacjami i kręgami towarzyskimi młodych podróżników. Do zabieranych w podróż sztambuchów wpisywali się najbliżsi przyjaciele, nauczyciele, napotykani na trasach inni młodzi szlachcice, znani uczeni, sławne osobistości całej Europy, a czasem również współtowarzysze podróży. Do albumów przyjaciół trafiały okolicznościowe dedykacje i wiersze, na zdobionych kartach znajdowały się liczne sentencje moralne, a poszczególne wpisy wieńczyły herby nowych znajomych, czasem również zabawne scenki rodzajowe i rysunki o różnej treści. O ile na kartach dzienników odnotowywano trasę podróży i zwiedzane obiekty, o tyle w prowadzonych przez młodzieńców sztambuchach pozostawał ślad po nawiązanych w drodze, często przelotnych znajomościach. Sztambuchy były szczególnie popularne w środowisku protestanckim w XVI i XVII wieku, podobne wpisy kolekcjonowała jednak również w czasie podróży katolicka szlachta z terenów Rzeczypospolitej Obojga Narodów. Opracowania doczekały się niektóre sztambuchy związane z mieszkańcami Rzeczypospolitej i zagadnienia dotyczące

A. Markiewicz, Instrukcja hetmana Stanisława Jabłonowskiego do synów Jana Stanisława i Aleksandra Jana z 1682 r. [w:] Spoleczeństwo a rodzina, Spoleczeństwo Staropolskie. Seria Nowa, t. III, red. A. Karpiński, Warszawa 2011, s. 49. Szerzej o podróży wojewodziców ruskich Jabłonowskich zob. A. Markiewicz, Peregrinationes Jablonovianae. Grand tour w czasach Jana III Sobieskiego, Warszawa 2011, passim. Podobnie Stanisław Jabłonowski polecał w 1682 r. wyruszającemu z jego synami w podróż zagraniczną młodemu Mateuszowi Stanisławowi Rzewuskiemu: „A o to się WM P[anu] staraj, żebyś jako z najznamienitszymi ludźmi gadał i z niemi znajomość brał, et quam modestissime w dyskursach i konwersacyi z niemi postępował", Biblioteka Uniwersytetu Warszawskiego, rkps 92, k. 49v. Tekst instrukcji został wydany w XIX wieku jako: Informacya JM Panu Stanisławowi Rzewuskiemu starościcowi chetmskiemu, jadącemu do cudzych krajów, od JM Pana Jabłonowskiego, hetmana wielkiego koronnego, „Tygodnik Ilustrowany” 1864, t. 9, nr 232, s. 91. 
dokonywanych w nich wpisów, zwykle jednak koncentrowano się na albumach pochodzących z końca XVI i pierwszej połowy XVII stulecia 6 .

Do dziś nie zachowało się wiele sztambuchów prowadzonych przez młodych polskich szlachciców i podróżników, choć wzmianki o istnieniu podobnych albumów przetrwały czasem w innych relacjach podróżniczych ${ }^{7}$. Tym cenniejsze wydają się nieznane wpisy młodych szlachciców z ziem Rzeczypospolitej Obojga Narodów utrwalone w sztambuchach prowadzonych przez innych podróżników. Umożliwiają one odtworzenie przebiegu danej podróży edukacyjnej, przynoszą szczegóły dotyczące trasy grand tour, a czasem stanowią jedyną wzmiankę źródłową o pobycie szlachciców i magnatów na zachodzie Europy z drugiej połowy XVII wieku.

$\mathrm{Na}$ szczególną uwagę zasługuje przechowywany w bogatym zbiorze sztambuchów w British Library cenny album zawierający nieznane wpisy podróżników z Rzeczypospolitej Obojga Narodów - odbywających w latach 60. XVII wieku podróż edukacyjną po Europie młodych Tarłów ${ }^{8}$. Należący do rezydującego we Florencji anonimowego szlachcica (pochodzącego najprawdopodobniej z ziem Rzeszy Niemieckiej) sztambuch zawiera liczne wpisy z lat 1660-1669. Na jego kartach

${ }^{6}$ Zob. zwłaszcza: Z. Pietrzyk, Sztambuchy jako źródto do peregrynacji studenckich na przykładzie Polaków studiujących w Strasburgu, „Odrodzenie i Reformacja w Polsce” 1999, t. 43, s. 139-150; idem, Przyczynek do studiów zagranicznych Mikołaja Ostroroga i Jakuba Sobieskiego, „Odrodzenie i Reformacja w Polsce” 1998, t. 42, s. 139-144; idem, W kręgu Strasburga...; E. Kotarski, O imionnikach XVI i XVII wieku [w:] Staropolska kultura rękopisu, red. H. Dziechcińska, Warszawa 1990, s. 93-111; A. Golik-Prus, Różnorodność formuly ,non omnis moriar” w tacińskich wpisach sztambuchowych przełomu XVI i XVII w., Katowice 2004; eadem, Poezja figuratywna na kartach sztambuchów z przetomu wieku XVI i XVII, „Odrodzenie i Reformacja w Polsce” 2000, t. 44, s. 101-106; eadem, Dedykacje z Alba Amicorum przełomu wieków XVI i XVII w zbiorach Biblioteki Jagiellońskiej jako źródto biograficzne, „Biuletyn Biblioteki Jagiellońskiej”, R. 49, 1999, s. 137-141; eadem, Kobiece wpisy sztambuchowe w Polsce XVI-XVII wieku, „Biuletyn Biblioteki Jagiellońskiej”, R. 48, 1998, s. 13-21; eadem, Wpisy Daniela Naborowskiego do ,, alba amicorum”, „Pamiętnik Literacki” 1997, z. 4, s. 145-151; C. Pirożyńska, Sztambuch Daniela Naborowskiego, „Biuletyn Biblioteki Jagiellońskiej”, R. 21, 1971, s. 93-104; K. Kotońska, Album przyjaciót Jana Naeranusa, „Odrodzenie i Reformacja w Polsce” 1990, t. 34, s. 169-206; E. Rastawiecki, Imionnik cudzoziemców A. Kazanowskiego, „Biblioteka Warszawska” 1853, t. 50, s. 441-479; S. Bodniak, Album amicorum Jana Zborowskiego, „Silva rerum” 1927, n. 11-12, s. 174-179; A. Chmiel, ,,Imionnik” z 1582 r. Jana Alembeka aptekarza, „Nowe Czasopismo Aptekarskie" 1920, s. 4-12; E. Białek, W. Mrozowicz, Polonische Einträge in den Stammbüchern der Universitätsbibliothek Wroctaw, „Acta Universitatis Wratislaviensis” 1985, t. 891, s. 111-132; 1986, t. 954, s. 327-330; K. Now aczyk, Hafty w sztambuchach Biblioteki Uniwersyteckiej w Poznaniu, „Biblioteka" 2011, 15/24, s. 281-294; J. Ziembiński, Manu propria. Wpis Olbrychta Karmanowskiego do Liber amicorum Andrzeja Lubienieckiego, „Odrodzenie i Reformacja w Polsce” 2013, t. 57, s. 154-169; J. Pelc, Stowo i obraz. Na pograniczu literatury i sztuk plastycznych, Kraków 2002, s. 312-313.

7 Przykładem mogą być wydatki odnotowane w rachunkach podróży Jana Ługowskiego z pierwszej połowy XVII w.: „Za malowanie herbu w książkę JMP Dobraczyńskiego”, ,Za herb Jasiów malarzowi w książki JMP Madalińskiego”, „Za herb JMP Madalińskiego w książki Jasiowe” czy „Za herb Katiniego w książki p. Jana", Jasia Ługowskiego podróże do szkót w cudzych krajach 1639-1643, oprac. K. Muszyńska, Warszawa 1974, s. 223, 280. Podobnie z wpisami do sztambuchów można najprawdopodobniej wiązać rachunki za malowanie herbu młodego Stanisława Lubomirskiego, W. Czapliński, J. Długosz, op. cit., s. 191, 193.

8 British Library [dalej: BL], Add MS 4976, Album Amicorum of a gentleman, probably of German or Austrian origin, resident at Florence; 1660-15 Mar. 1669. 
znalazło się 87 wpisów w językach łacińskim, francuskim, niemieckim, hiszpańskim i włoskim, a wśród młodych szlachciców dokonujących wpisu do albumu dominują odwiedzający Florencję w latach 60. XVII wieku podróżnicy z ziem niemieckich.

$\mathrm{Na}$ trzech kartach sztambucha znajdują się wpisy młodych Tarłów, wzbogacające wiadomości o edukacji i podróżach przedstawicieli tej rodziny. Siedemnastowieczną edukację rodziny Tarłów przedstawił w cennym opracowaniu Marian Chachaj ${ }^{9}$, a wpisy z przechowywanego $\mathrm{w}$ Londynie sztambucha pozwalają na uzupełnienie itinerarium młodych szlachciców o nieznany etap ich peregrynacji.

Na pierwszej ze związanych z rodziną Tarłów kart sztambucha znalazł się pochodzący z 1663 roku wpis młodego Adama Tarły ${ }^{10}$. Na karcie albumu dominuje kolorowa, precyzyjnie wykonana tarcza herbowa pieczętującej się herbem Topór rodziny Tarłów. Na tarczy herbowej w polu czerwonym znajduje się topór srebrny o stylisku złotym, w klejnocie godło w skos, nad tarczą złota korona, labry błękitne i czerwone podbite srebrem. Cała tarcza została okolona drobiazgowo namalowanym wieńcem roślinnym, składającym się z czerwonych i błękitnych kwiatów, którym towarzyszą jasno- i ciemnozielone cieniowane listki. Całość kompozycji zachwyca starannością wykonania oraz doborem barw. Nad tarczą herbową, w lewym górnym rogu karty, widnieje malowana i zdobiona w kolorach błękitu i czerwieni szarfa z sentencją: „Per Ardua". W prawym dolnym rogu karty, na dekoracyjnej filakterii, znajduje się wpis młodego podróżnika: „Adamus de Sczekarzowice Tarło comes in Melsztyn An[no] 1663 ".

$\mathrm{Na}$ kolejnej karcie sztambucha figuruje wpis innego przedstawiciela tej rodziny, młodego wojewodzica lubelskiego Karola Tarły ${ }^{11}$. W albumie przyjaciół został powtórzony rysunek herbu z poprzedniego wpisu. Na karcie widnieje identyczny, wykonany tą samą ręką herb Topór - na tarczy herbowej w polu czerwonym znajduje się topór srebrny o stylisku złotym, w klejnocie godło w skos, nad tarczą złota korona, labry błękitne i czerwone podbite srebrem. Tym razem herb został powtórzony bez ozdoby w postaci otoku z kwiatowej girlandy. Nad tarczą herbową, centralnie na karcie, umieszczono szarfę z dewizą: „Pro fide et patria”, boki wstęgi pomalowano na kolor czerwony i złoty. Na dole karty, pod tarczą herbową, na zwiniętej ozdobnej wstędze znajduje się wpis młodego szlachcica: „Carolus de Tęczyn Tarło P[alatinides] L[ublinensis]".

Autorem trzeciego interesującego nas wpisu w albumie przyjaciół nieznanego podróżnika był brat poprzednika, młody wojewodzic lubelski Aleksander Tarło ${ }^{12}$. Na

9 M. Chachaj, Wykształcenie Tarłów od połowy XVII do końca XVIII wieku [w:] Tarłowie. Z dziejów kulturalnych, gospodarczych i politycznych rodu, t. 2, red. H. Gmiterek, A. Szymanek, Janowiec nad Wisłą 2009, s. 9-31; idem, Jeszcze o wykształceniu Tartów od połowy V do polowy XVII wieku [w:] Tarlowie..., t. 2, s. 33-35; zob. również: idem, Wyksztatcenie Tartów od polowy XV do połowy XVII wieku [w:] Tartowie. Rola i znaczenie rodziny w dziejach ogólnonarodowych i lokalnych XVI-XIX wieku. Materiaty sesji naukowej 24 czerwca 2006, red. H. Gmiterek, A. Szymanek, Janowiec nad Wisłą 2006 [2007], s. 52-71.

10 BL, Add MS 4976, Album Amicorum of a gentleman, probably of German or Austrian origin, resident at Florence; 1660-15 Mar. 1669, k. 84.

11 Ibidem, k. 85.

12 Ibidem, k. 86. 
środku karty znajduje się tarcza herbowa $\mathrm{z}$ herbem Topór, tym razem skromnie wykonana, bez licznych zdobień, na tarczy herbowej w polu czerwonym widnieje złoty topór. Zabrakło tutaj klejnotu i labrów, jedynie sama tarcza została ozdobiona dodatkowym niewielkim błękitnym obramowaniem o złotych brzegach. Ponad herbem młodego podróżnika, na górze karty sztambucha, znajduje się centralnie umieszczona szarfa z napisem: „Omnia sponte fluant, absit violentia rebus”, dewiza pochodząca z dzieła Jana Amosa Komeńskiego (1592-1670) Orbis sensualium pictus, znanego zapewne podróżnikom popularnego elementarza wydanego niedawno, bo w 1658 roku w Norymberdze ${ }^{13}$. Poniżej tarczy herbowej, na dole karty umieszczono zwiniętą czerwoną wstęgę, na niej wpis z datacją precyzującą szczegóły pobytu młodzieńca we Florencji: „A Fiorenza a 3 di Maggio Alexander Tarło Conte de Tenczyn A[nno] D[omini] 1663”.

Warto przybliżyć postacie młodych podróżników i spróbować umiejscowić ich pobyt w stolicy Wielkiego Księstwa Toskanii w czasie całej podróży edukacyjnej. Autor pierwszego $\mathrm{z}$ wpisów w należącym do anonimowego właściciela sztambuchu to Adam Tarło (zm. 1710), najstarszy syn kasztelana przemyskiego Zygmunta Aleksandra Tarły i Elżbiety Kostczanki ${ }^{14}$, późniejszy podczaszy przemyski $(1671)^{15}$ i wojewoda smoleński $(1691)^{16}$. Poznano dotąd zarys jego krajowej edukacji i zagranicznej podróży edukacyjnej, ze względu na brak innych źródeł pewne były jedynie informacje o jego pobycie w Rzymie i Padwie ${ }^{17}$. Nieznany dotąd wpis ze sztambucha pozwala więc na uzupełnienie itinerarium młodego podróżnika o Florencję. Adam Tarło pobierał nauki w Krakowie, w Szkołach Nowodworskich ${ }^{18}$, a następnie podjął studia w Akademii Krakowskiej ${ }^{19}$. Jeszcze w Szkołach Nowodworskich jednym z jego nauczycieli i egzaminatorem z zakresu dialektyki był Jan Stanisław Rudzki. Pod jego opieką w latach 60. XVII wieku Adam Tarło wyjechał w niezbędną dla szlachcica podróż edukacyjną po zachodniej Europie. Młody człowiek miał odwie-

13 A. Fijakowski, Tradycja i nowatorstwo w Orbis sensualium pictus Jana Amosa Komeńskiego, Warszawa 2012.

14 W. Wierowski, Caelatura phoebi in armis gentilitiis nobilissimae et antiquissimae Toporum familiae editi [...] Sigismundi Tarto [...] sub tempus hymenaeo sacrum, quo cum [...] Elisabetha Kostczanka [...] sacrum nuptiarum inibat, Cracoviae [1636].

${ }_{15}$ Urzędnicy województwa ruskiego XIV-XVIII wieku (ziemie halicka, lwowska, przemyska, sanocka). Spisy, oprac. K. Przyboś, Wrocław-Warszawa-Kraków-Gdańsk-Łódź 1987, nr 1843, s. 218.

${ }^{16}$ Urzędnicy Wielkiego Księstwa Litewskiego. Spisy, t. 4: Ziemia smoleńska i województwo smoleńskie XIV-XVIII wieku, red. A. Rachuba, oprac. H. Lulewicz, A. Rachuba, P.P. Romaniuk, Warszawa 2003, nr 1619.

17 Edukację Adama Tarły wyczerpująco omawia w cennym artykule M. Chachaj, Wykształcenie Tartów od połowy XVII do końca XVIII wieku, s. 9-11.

18 Biblioteka Jagiellońska, rkps 127, Orationes variae in oratorio academico recitate, Anno 1643 1698, „Centuriata Reipublicae literariae comitia, in quibus avito Poloniae more duodecim palatinide de retinenda veteris Poloniae dignitate ineunt rationes, philorethores autem in palestra Tyliciana ad Ciceronianas in genere deliberative formas easdem repraesentabant, in Collegio Maiori lectorio Galeni celebrata per M. Ioannis Radzki, s. th. et Tylicianum eloquentiae ordinarium Professorem, Anno Domini 1658 VIII Idus De[cembris], praesidens comitiorum Alexander Tarło, palatinides Lublinensis", k. 174v.

19 F. Lepiecki, Secunda vota secunda omnia lextissimis neosponsis [...] Georgio Lubomirski [...] et [...] Barbarae de Sczekarzowice Tartoviae [...], Cracoviae [1655], k. A v. 
dzić Niderlandy, Francję i Włochy. Guwerner młodzieńca, ceniony panegirysta Jan Stanisław Rudzki (zm. po 1683) ${ }^{20}$, był jednym z wielu krakowskich akademików, którzy towarzyszyli młodym szlachcicom w ich podróżach edukacyjnych. Dedykował on swemu podopiecznemu, kasztelanicowi przemyskiemu Adamowi Tarle, dzieło spisywane prawdopodobnie w czasie zagranicznej podróży i ukończone w Rzymie 5 września 1664 roku, wydane w Krakowie już po powrocie, w roku następnym ${ }^{21}$. W dedykacji, wśród licznych pochwał pod adresem wychowanka i wspomnień z okresu krakowskiej edukacji, znalazł się również następujący passus:

Subsistis in Belgio, perlustras ordinatissimas Hollandiae Provincias, ut regimen prudentissimum, ad consummatae prudentiae apparatum transferas. Galliae Principes dum consalutas maximos, praeclarum Te exterorum magnificentiam, et exercitationes omnes bellicas, traxisse Lutetiis contestantur. Veneraris in Romano orbis theatro supremam in terris maiestatem, Purpuratosque Ecclesiae Patres, in amorem Tui dum pertrahis, illi Te intus et foris praeclare exornatum ore et corde complectuntur. Sic comitate Tua dulci, liberalitate magnifica, magnanimitate generosa, mansuetudine amabili, observantia Tui sapientissimi Gubernatoris omnibus imitanda, castimonia vitae laudabili, pietate in Deum eximia, triumphas in triumphali Romana sede, redux in patriam non cum laude solum, sed etiam desiderio omnium, in Tuos amplexus ruentium ${ }^{22}$.

Pomijając wyszukane pochwały pod adresem młodzieńca, warto zwrócić uwagę na bardzo ogólnie zarysowaną trasę podróży kasztelanica i jego opiekuna. Okazuje się, że pierwszym etapem peregrynacji były Niderlandy. Niestety nie wiadomo, czy dotarli tam popularną drogą wodną z Gdańska, czy lądem. Stąd przez Paryż udali się na południe Europy i dalej do Rzymu.

Młody szlachcic przebywał w Wiecznym Mieście do września 1664 roku. Jeszcze wiosną 1664 roku, zapewne w drodze na południe i do Rzymu, Adam Tarło odwiedził Padwę. Jego pobyt w tym ośrodku akademickim można jedynie ogólnie datować na okres między lutym a majem tego roku ${ }^{23}$. Dzięki zapisowi w sztambuchu można na jeszcze wcześniejszy okres (1663) datować pobyt młodego Adama Tarły we Florencji. Przypuszczalnie przybył on tutaj z Paryża, kierując się na południe Europy. Florencja stanowiła stały punkt programu dla wszystkich szlachciców odbywających

${ }^{20}$ K. Fokt, Rudzki (Rucki) Jan Stanisław [w:] K. Ożóg, K. Fokt, M. Mikuła, M. Zdanek, D. Wójcik-Zega, K. Kuras, Profesorowie Wydziału Prawa Uniwersytetu Jagiellońskiego, t. I: 1364 1780, red. W. Uruszczak, Kraków 2015, s. 362-363.

${ }_{21}$ J.S. Rudzki, Isagoge politica, seu magnanimae iuventutis Polonae introductio, ad rempublicam liberam: in qua ostenditur cunctis Regium iter ad honores capessendos, et rite obeunda munera publica [...], Cracoviae 1665.

22 Ibidem, k. $\mathrm{A}_{5} \mathrm{v}-\mathrm{A}_{6}$.

${ }_{23}$ Archiwum nacji polskiej w Uniwersytecie Padewskim, t. I: Metryka nacji polskiej w Uniwersytecie Padewskim (1592-1745), oprac. H. Barycz, indeks osób oprac. K. Targo sz, Wrocław-WarszawaKraków-Gdańsk 1971, s. 139, nr 1763. O metrykach zagranicznych uniwersytetów jako ważnym źródle do badań nad staropolską kulturą: M. Chachaj, Metryki zagranicznych uniwersytetów i akademii jako źródto do dziejów kultury polskiej (XVI-XVII w.) [w:] Studia z dziejów epoki renesansu, red. H. Zins, Warszawa 1979, s. 37-56. 
podróż edukacyjną, zwykle kilka lub kilkanaście dni poświęcano na zwiedzanie miasta i zapoznawanie się z jego zabytkami ${ }^{24}$.

W stolicy Wielkiego Księstwa Toskanii młodzieniec najprawdopodobniej spotkał swoich krewnych, wojewodziców lubelskich. W maju 1663 roku we Florencji przebywali bowiem Karol i Aleksander Tarłowie. Byli to dwaj synowie wojewody lubelskiego Aleksandra Piotra Tarły (zm. 1649), który sam w młodości odbył zagraniczną podróż edukacyjną, odwiedzając między innymi Strasburg ${ }^{25}$ i Genewę ${ }^{26}$. Co ciekawe, Aleksander Piotr Tarło w czasie młodzieńczej podróży prowadził sztambuch ${ }^{27}$. Wojewoda lubelski z pierwszego małżeństwa z Zofią Działyńską miał czterech synów: Mikołaja, Jana, Stefana i Władysława Kazimierza, którzy odebrali odpowiednią edukację w krakowskich Szkołach Nowodworskich, a następnie wyruszyli w zagraniczne podróże edukacyjne. Aleksander Piotr Tarło z drugiego małżeństwa z Jadwigą Lanckorońską również miał czterech synów: Karola, Aleksandra, Stanisława i Zygmunta. Odebrali oni wykształcenie już po śmierci ojca, zmarłego w 1649 roku. To właśnie Karol i Aleksander razem odwiedzili Florencję w maju 1663 roku.

Karol Tarło (zm. 1702) to późniejszy wojewoda lubelski (1685-1689) ${ }^{28}$ i podkanclerzy koronny w latach 1689-1702, przed śmiercią w listopadzie 1702 roku nominowany na kanclerza koronnego ${ }^{29}$. Jego młodszy brat, wcześnie zmarły Aleksander Tarło (zm. 1683), pełnił urząd kasztelana zawichojskiego ${ }^{30}$. Podobnie jak starsi bracia Karol i Aleksander rozpoczęli edukację w krakowskich Szkołach Nowodworskich. W 1658 roku obaj wystąpili w akademickiej dyspucie przygotowanej pod kierunkiem profesora Uniwersytetu Krakowskiego Jana Radzkiego. Przewodniczył jej młody Aleksander Tarło ${ }^{31}$. Warto dodać, iż w inscenizowanych obradach sejmiku brał udział również ich krewny, wspomniany wyżej kasztelanic przemyski Adam Tarło.

$24 \mathrm{O}$ miejscu Florencji na trasach grand tour zob. R. Sweet, Cities and the Grand Tour. The British in Italy, c. 1690-1820, Cambridge 2012, s. 65-98; J. Black, Italy and the Grand Tour, s. 45; zob. również M. Wrześniak, Florencja - Muzeum. Miasto i jego sztuka w oczach polskich podróżników, Kraków 2013.

25 Z. Pietrzyk, W kręu Strasburga..., s. 229.

26 M. Chachaj, Wykształcenie Tarłów od połowy XV do połowy XVII wieku, s. 65.

27 Idem, Zagraniczna edukacja Radziwiłtów..., s. 127, przyp. 62.

28 Urzędnicy województwa lubelskiego XVI-XVIII wieku. Spisy, oprac. W. Kłaczewski, W. Urban, red. A. Gąsiorowski, Kórnik 1991, nr 382, s. 58.

${ }_{29}$ Urzędnicy centralni i nadworni Polski XIV-XVIII wieku. Spisy, oprac. K. Chłapowski, S. Ciara, Ł. Kądziela, T. Nowakowski, E. Opaliński, G. Rutkowska, T. Zielińska, red. A. Gąsiorowski, Kórnik 1992, nr 675, s. 113; nr 231, s. 57.

30 Urzędnicy województwa sandomierskiego XVI-XVIII wieku. Spisy, oprac. K. Chłapowski, A. Falniowska-Gradowska, red. A. Gąsiorowski, Kórnik 1993, nr 1346, s. 163.

31 Biblioteka Jagiellońska, rkps 127, Orationes variae in oratorio academico recitate a. 1643-1698, „Centuriata Reipublicae literariae comitia, in quibus avito Poloniae more duodecim palatinide de retinenda veteris Poloniae dignitate ineunt rationes, philorethores autem in palestra Tyliciana ad Ciceronianas in genere deliberative formas easdem repraesentabant, in Collegio Maiori lectorio Galeni celebrata per M. Ioannis Radzki, s. th. et Tylicianum eloquentiae ordinarium Professorem, A[nno] D[omini] 1658 VIII Idus Decembris, praesidens comitiorum Alexander Tarło, palatinides Lublinensis”, k. 171, $174 \mathrm{v}, 178$. Zob. H. Barycz, Historia szkół nowodworskich, Kraków 1988, s. 218-220. 
Wojewodzice lubelscy Aleksander i Karol Tarłowie odwiedzili Padwę jeszcze w 1662 roku, wpisali się do metryki nacji polskiej 25 lutego ${ }^{32}$. W lutym 1663 roku przebywali w Rzymie. 25 lutego 1663 roku ich obecność, wśród licznych Polaków przebywających w Wiecznym Mieście, odnotowali inni młodzi podróżnicy - kasztelanice krzywińscy Wojciech i Andrzej Radolińscy, którzy podróżowali właśnie po Europie pod opieką Jana Nyczkowicza: „Zastaliśmy tu IchMM. PP. Polaków: Jmci X. Zebrzydowskiego, IchMM. PP. Tarłów wojewodziców lubelskich, IchMM. PP. Pineciów, IchMci X. Łubieńskiego, kanonika krakowskiego, Jmci X. Cesarego, Jmci X. Żórawskiego, Jmci Pana Różyckiego, Jmci X. Glasneckiego, Jmci Pana Kłosowskiego, Jmci Pana Osiusza"33. Latem 1663 roku odwiedzili Orlean ${ }^{34}$. We wrześniu 1663 roku byli już w Paryżu, gdzie ich pobyt ponownie został odnotowany przez młodego Wojciecha Radolińskiego ${ }^{35}$. Datowany na maj 1663 roku wpis ze sztambucha pozwala na drobne uzupełnienie itinerarium podróży: Florencję wojewodzice lubelscy musieli odwiedzić w drodze z Rzymu do Paryża.

Na uwagę zasługuje kwestia kontaktów towarzyskich nawiązywanych przez młodych szlachciców w czasie podróży, co doskonale obrazuje przypadek młodych Tarłów. Na kartach sztambuchów można odnaleźć cenne informacje dotyczące wielu podróżników z ziem Rzeczypospolitej Obojga Narodów, odbywających właśnie podróże edukacyjne po krajach Europy Zachodniej, tak ważne dla badań nad kręgami towarzyskimi i kontaktami interpersonalnymi w czasie peregrynacji ${ }^{36}$.

Wyruszający w podróż edukacyjną szlachcice prowadzili zwykle ożywione życie towarzyskie, zawierając liczne znajomości i składając rewizyty zarówno rodakom, jak i przedstawicielom innych nacji.

Wspomniany wyżej wypis z dziennika podróży młodych Radolińskich dobrze oddaje pierwsze chwile młodych ludzi po przybyciu do dużego europejskiego miasta. Spisywane przed wyjazdami do Paryża czy Rzymu instrukcje rodzicielskie zwykle odradzały zbyt częste spotkania z mieszkańcami Rzeczypospolitej. Hetman Jabłonowski również zalecał synom, aby „z Panami Polakami [...] żadnej częstej nie miewali konwersacji, a jeżeli się nie będzie mogło obejść bez tego to barzo krótko

32 Archiwum nacji polskiej w Uniwersytecie Padewskim..., s. 137, nr 1740, 1741.

33 [W. Radoliński], Pamiętnik podróży odbytej roku 1661-1663 po Austryi, Włoszech i Francyi, wyd. Z. C [elichowski], Torun 1874, s. 40.

34 M. Chachaj, Wyksztatcenie Tartów od połowy XV do połowy XVII wieku, s. 69-70. O obecności młodych mieszkańców Rzeczypospolitej w Orleanie zob. S. Kot, Polacy na studiach w Orleanie w XVI i XVII wieku, „Sprawozdania z Czynności i Posiedzeń Polskiej Akademii Umiejętności” 1920, nr 5, s. 2-3.

35 Młody szlachcic dotarł właśnie w połowie września z Orleanu do Paryża, gdzie zapisał: „Z Aurelii, tu język francuski nieźle zrozumiawszy i insze exercitia cudzoziemskie po większej części odprawiwszy, puściliśmy się do Paryża in medio Septembre, gdzie trzeciego dnia stanęliśmy blisko Sorbony na ulicy S. Jacques au petit S. Charles. Zastaliśmy tu Ich MM. PP. Polaków niemało, osobliwie Ich MM. PP. Sapiehów, Ich MM. PP. Tarłów i PP. Radziejewskich, Jmci Pana Cetnera i inszych tak wiele", [W. Radoliński], op. cit., s. 63.

${ }^{36} \mathrm{Na}$ znaczenie kontaktów towarzyskich w czasie zagranicznych podróży zwrócił uwagę B. Rok, Życie towarzyskie Teofili z Radziwiltów Morawskiej w europejskiej podróży w latach 1773-1774 [w:] Wtadza i prestiż. Magnateria Rzeczypospolitej w XVI-XVIII wieku, red. J. Urwanowicz, Białystok 2003, s. 639-649. 
i barzo rzadko, gdyż przez to i w naukach i w obyczajach i w języku wielką szkodę zwykli ponosić nasi peregrynanci" ${ }^{37}$. Negatywne skutki intensywnych kontaktów między Polakami podkreślał również Jakub Sobieski ${ }^{38}$. Podobnie w 1728 roku Jan Stanisław Jabłonowski pisał w instrukcji sporządzonej dla wyruszającego w podróż zagraniczną bratanka: „Polacy rzadko doskonale umieją gadać po francusku, bo cały czas trwają z Polakami, z któremi się w Polszcze nagadać trzeba ich evitare i w takim stanąć quartur, gdzie sami Francuzi, bo między bracią i przeszkoda do nauk i swywola i w języku ujma francuskim. Nie mówię, żeby absolute z Polakami się nie widywać, to by mogło odium parere, ale raz wizyty odbywszy odłożyć z niemi familiaritates do Polski" ${ }^{39}$. Praktyka codziennego życia znacznie odbiegała niekiedy od teorii precyzowanej w zaciszu rodzinnego dworu, mieszkańcy Rzeczypospolitej nawiązywali liczne kontakty towarzyskie, a spotkania $\mathrm{z}$ rodakami stanowiły stały punkt wielkiej podróży po Europie. Karty podróżnych dzienników często stanowią cenne źródło odnotowujące przyjazdy kolejnych rodaków i umożliwiające rekonstrukcję podróżnych itinerariów ${ }^{40}$.

Jak wynika z dziennika Radolińskich, młodzi Tarłowie również podtrzymywali kontakty z mieszkańcami Rzeczypospolitej w czasie zagranicznej podróży po Europie. Warto dodać, iż w tym samym czasie co Tarłowie zagraniczną podróż edukacyjną odbywali choćby młodzi bracia Ossolińscy - synowie podskarbiego nadwornego koronnego Maksymiliana Franciszka ${ }^{41}$, wojewodzice wileńscy Benedykt Paweł, Kazimierz Jan i Franciszek Stefan Sapiehowie ${ }^{42}$, Marcin Chomętowski ${ }^{43}$ czy ich znajomy

37 A. Markiewicz, Instrukcja hetmana Stanistawa Jablonowskiego..., s. 54.

38 Sobieski pisał w instrukcji dla synów Jana i Marka: „Co się zaś tknie konwersacjej z naszemi Polakami, tu już miłością moją ojcowską proszę Was dla Pana Boga, który stworzył niebo i ziemię, rozkazuję i zaklinam Was pod moim ojcowskim błogosławieństwem, abyście sobie jako najostrożniej postępowali i Pana Boga o to proszę i prosić będę, aby jako najmniej Polaków było, gdzie Wy będziecie stać, bo po prostu nasi radzi się z sobą wadzą, i na drugiego radzi podusczają, nowinki sieją jeden o drugim, jeden drugiemu ledeczego zajrzy, jeden drugiego psuje złym przykładem, złymi obyczajami, na złe rzeczy namawiają, radzi podusczają na starszych, na utraty niepotrzebne. Rzadki z nich czym się tam dobrze bawi”. S. Gawarecki, Diariusz drogi. Podróż Jana i Marka Sobieskich po Europie 1646-1648, oprac. M. Kunicki-Goldfinger, Warszawa 2013, s. 67-68.

39 Biblioteka XX. Czartoryskich, rkps 1162 IV, Raptularz domu Jabłonowskich, k. 630.

40 Przykładem może być relacja Stanisława Wierzbowskiego. Po przyjeździe do Paryża w styczniu 1679 r. podaje on długą listę przebywających tam właśnie Polaków: Peregrynacja Stanisława Wierzbowskiego wojewodzica sieradzkiego do Francji w latach 1678, 1679, 1680 i 1681, wyd. J.K. Załuski, „Czas” (dodatek miesięczny) 1858 (marzec), t. IX, s. 501-502. O kontaktach i znaczeniu podróżnych znajomości zob. również A. Markiewicz, Peregrinationes Jablonovianae..., s. 39-42; W. Tygielski, op. cit., s. 155.

${ }^{41}$ Dziennik podróży po cudzych krajach odbytej w latach 1660-1663, wyd. Ł. Tatomir, „Biblioteka Ossolińskich. Poczet Nowy” 1864, t. 5, s. 303-397; Biblioteka Zakładu Narodowego im. Ossolińskich we Wrocławiu, rkps 230; J. Długosz, Ossoliński Maksymilian, PSB, t. 24, Wrocław-Kraków 1979, s. $423-424$.

42 A. Rachuba, Sapieha Benedykt Pawet, PSB, t. 34, Wrocław-Warszawa 1992-1993, s. 583-591; idem, Sapieha Kazimierz Jan Pawet, PSB, t. 35, Warszawa-Kraków 1994, s. 37-48; idem, Sapieha Franciszek Stefan, PSB, t. 34, Wrocław-Warszawa 1992-1993, s. 602-604.

${ }_{43}$ Archiwum nacji polskiej w Uniwersytecie Padewskim..., s. 139, nr 1761; K. Piwarski, Chomętowski Marcin, PSB, t. 3, Kraków 1937, s. 411. 
jeszcze z krakowskich Szkół Nowodworskich - kasztelanic halicki Jan Aleksander Cetner ${ }^{44}$ wraz z preceptorem Adamem Kazimierzem Wasilewskim ${ }^{45}$.

Przytoczone wyżej sztambuchowe wpisy świadczą jednak o tym, że młodzi Tarłowie nie ograniczali się wyłącznie do grona przyjezdnych z Rzeczypospolitej, zawiązywali również inne znajomości i chętnie obracali się w gronie szlachty z całej Europy. Przeglądając album przyjaciół anonimowego podróżnika, warto zwrócić uwagę na kontakty Polaków ze szlachtą czeską i niemiecką, zawiązywane już zwykle w czasie pierwszego etapu grand tour. Podróżni wyruszający do Paryża, Florencji i Rzymu zatrzymywali się zazwyczaj właśnie na krótsze lub trwające nieco dłużej postoje w Pradze. W ostatniej ćwierci XVII stulecia dla młodej szlachty z ziem Rzeczypospolitej Praga stanowiła zwykle pierwszy przystanek w zagranicznej peregrynacji ${ }^{46}$. Młodzież przyswajała tam zwykle solidnie podstawy języka niemieckiego i pobierała mniej lub bardziej gruntowną edukację.

Nawiązywano tam również przyjaźnie i kontakty, które podtrzymywano już po wyjeździe z miasta. Przykładem może być podróż Stanisława Kazimierza Gonzagi Myszkowskiego (ok. 1660-1684) (7) $^{4}$ Edukacja w praskim kolegium stanowiła pierwszy etap jego grand tour, a wzmianki o jego praskiej edukacji poświadczające pobyt i naukę pojawiają się w dzienniku podróży dobrego przyjaciela młodego Myszkowskiego, Heřmana Jakuba Černína ${ }^{48}$. Myszkowski podróżował po Europie pod opieką doświadczonego guwernera, Włocha z pochodzenia, Tomasza Rochettiego (Rokietego $)^{49}$. Podobnie jak inni peregrynanci, po wyjeździe z Pragi Stanisław Kazimierz Myszkowski wyruszył na Półwysep Apeniński ${ }^{50}$ i do Francji. Młody Myszkowski w czasie podróży kilkakrotnie spotkał się ze swoim dobrym znajomym z czasu praskich studiów, Heřmanem Jakubem Černínem - młodzieńcy odwiedzali się w Rzymie, Turynie i Florencji ${ }^{51}$.

44 Z. Lasocki, Cetner Jan, PSB, t. 3, Kraków 1937, s. 239-240.

45 Archiwum nacji polskiej w Uniwersytecie Padewskim..., s. 137, nr 1746.

46 A. Markiewicz, „In limine cizího světa“. Jak se v Praze vzdělávala šlechta z polsko-litevského soustátí v poslední čtvrtině 17. století, „Acta Universitatis Carolinae. Historia Universitatis Carolinae Pragensis. Př́íspevky k dějinám Univerzity Karlovy" 2016, t. 2, fasc. 2 [w druku].

47 K. Przyboś, Myszkowski Franciszek, PSB, t. 22, Wrocław-Kraków 1977, s. 370.

48 W dniu 23 czerwca 1679 r. H.J. Černín spotkał się we Florencji z młodymi szlachcicami, którzy właśnie przyjechali ze Sieny, jak odnotowano w jego dzienniku podróży: „Był z nimi také consigliere [německého univerzitního] národa markýz Gonzaga, Polák, který był minulý rok mým kolegou v pražském ustavu", H.J. Černín na cestě za Alpy a Pyreneje, I: Cestovní denník Heřmana Jakuba Černina z let 1678-1682, eds. Z. Hojda, E. Chodějovska, M. Hajná, Al. Tesařikova, Praha 2014, s. 191.

49 Zob. A. Markiewicz, Peregrinationes Jablonovianae..., s. 93.

507 III 1679 r. Myszkowski wraz z Rochettim wpisał się do metryki nacji polskiej w Padwie; Archiwum nacji polskiej w Uniwersytecie Padewskim..., s. 162, nr 1970 i 1971. W tym samym roku odnotowano również jego kilkumiesięczny pobyt w Sienie i immatrykulację na tamtejszej uczelni, M. Chachaj, Związi kulturalne Sieny i Polski do końca XVIII wieku. Staropolscy studenci i podróżnicy w Sienie. Sieneńczycy i ich dzieła w Polsce, Lublin 1998, s. 122.

51 H.J. Černín odnotował kolejne spotkania z młodym Polakiem, H.J. Černín na cestě za Alpy a Pyreneje, II: Cestovni denník Heřmana Jakuba Černína..., s. 192, 194, 195, 262, 265-267, 290-293, 318-321, 630, 631, 686, 687, 704-707. 
Nie wiadomo niestety, jak wyglądały kontakty Tarłów z innymi wzmiankowanymi na kartach sztambucha szlachcicami. Bez wątpienia jednak młodzi ludzie spotykali się we Florencji i w czasie grand tour z przedstawicielami najlepszych rodzin $\mathrm{z}$ terenów monarchii Habsburgów ${ }^{52}$. Florencję odwiedzili w tym czasie odbywający wielką podróż po Europie bracia Jan Norbert (zm. 1678) i Václav Vojtěch Sternbergowie, swój wpis w sztambuchu anonimowego podróżnika złożyli 14 grudnia 1663 roku podczas krótkiego, kilkudniowego pobytu w tym mieście ${ }^{53}$. Ich podróż edukacyjna rozpoczęła się już jesienią 1661 roku od dłuższego pobytu w akademii w Lowanium. Bracia odwiedzili następnie Londyn i Paryż, skąd udali się na południe Europy. Przez Mediolan, Modenę, Bolonię i Florencję wyruszyli do Rzymu. W Wiecznym Mieście przebywali od grudnia 1663 do września 1664 roku, stamtąd wrócili już do rodzinnego domu.

W 1663 roku, oprócz młodych Tarłów, wpisy w albumie złożyli między innymi podróżujący po Europie późniejszy arcybiskup praski Jan Fridrich von Valdstein $(1642-1694)^{54}$ i Franz Christoph von Herberstein, który następnie udał się do Sie$n^{55}$. W tych latach Florencję odwiedzili również młodzi bracia František Leopold Vilém (1639-1691) i Jan Karel Jachým (1641-1712) Slavatowie ${ }^{56}$, którzy przybyli tu z Lowanium, Georg Seyfried von Dietriechstein (1645-1714) $)^{57}$, Franz Ignac von Sprinzeinstein ${ }^{58}$ oraz Karel Maximilian Lažanškí z Bukové ${ }^{59}$.

Pobyt Adama, Karola i Aleksandra Tarłów we Florencji w 1663 roku doskonale wpisuje się w model ówczesnej podróży edukacyjnej, grand tour. Młodzi szlachcice pochodzący z Rzeczypospolitej Obojga Narodów, podobnie jak ich rówieśnicy z całej Europy, przemierzali cały kontynent, a metafora „Vita nostra peregrinatio est” ${ }^{\circ 0}$ gościła na kartach wielu sztambuchów. Młodzieńcy odwiedzali największe

52 O miejscu Florencji na trasach ówczesnych podróży szlachty czeskiej i niemieckiej zob. J. Kubeš, Náročne dospiváni urozených. Kavalirské cesty české a rakouské šlechty (1620-1750), Pelhřimov 2013, s. $24-32$.

53 BL, Add MS 4976, k. 47, o ich podróży zob. J. Kubeš, op. cit., s. 388-389; E. Chodějovská, I giovani nobili provenienti dalle Terre ceche nel loto viaggio d'educazione a Roma. Topografia della loro vita quotidiana nella Città eterna del XVII secolo, „Bolletino dell'Istituto storico ceco di Roma” 2012, bolletino 8, s. 90, 98, 111; o tezach uniwersyteckich Jana Norberta i Václava Vojtěcha Sternbergów: P. Zelenková, "Vidi stellas undecim”. Šternberské alegorie na grafických listech podle Karla Škréty, „Umění” 2006, t. 54, s. 327-342.

${ }_{54}$ BL, Add MS 4976, k. 26. Wpis: „Joannes Fridericus comes a Waldstein/ 16636 [Septem]bris”.

55 BL, Add MS 4976, k. 25. Wpis: „Francesco Christophoro conte de Herberstein”, dewiza „Mors omnia solvit 1663". Znany jest jego pobyt w Sienie: Die Matrikel der Deutschen Nation in Siena (15731738), ed. F. Weigle, t. I (Bibliotek des Deutschen Historichen Instituten in Rom, XXII), Tübingen 1962, s. 313.

56 BL, Add MS 4976, k. 9. Wpis: „Francesco Leopoldo Gulielmo conte Slavata/ Giovan Carlo conte Slavata/ 7 [Octo]bre 1661".

57 BL, Add MS 4976, k. 3. Dewiza: „Amor regge senza legge”, poniżej herb i wpis „Georgio Sigefrido conte di Dietrichstammo 1665”. Młodzieniec odwiedził w tym roku również Sienę, Die Matrikel der Deutschen Nation in Siena, s. 315, J. Kubeš, op. cit., s. 78.

58 BL, Add MS 4976, k. 46. Wpis: „François Ignace conte de Sprinzenstein et Neuhaus/ Florence le 6 de Novembre 1663".

59 BL, Add MS 4976, k. 10.

60 BL, Add MS 19640, k. 3. 
i najpopularniejsze ośrodki akademickie i zwiedzali kolejne miasta, chętnie nawiązując nowe kontakty. Zwykle zarzucano Polakom zbytnie zamykanie się we własnym gronie i w społeczności podróżujących, wpisy sztambuchowe i przykład młodych Tarłów poświadczają jednak, iż młodzi mieszkańcy Rzeczypospolitej nawiązywali również inne znajomości i chętnie obracali się w gronie europejskiej szlachty.

\section{BIBLIOGRAFIA}

\section{Źródła rękopiśmienne}

Biblioteka Jagiellońska, rkps 127.

Biblioteka Uniwersytetu Warszawskiego, rkps 92.

Biblioteka XX. Czartoryskich, rkps 1162 IV.

Biblioteka Zakładu Narodowego im. Ossolińskich we Wrocławiu, rkps 230.

British Library, Add MS 4976; Add MS 19640.

\section{Źródła drukowane}

Archiwum nacji polskiej w Uniwersytecie Padewskim, t. I: Metryka nacji polskiej w Uniwersytecie Padewskim (1592-1745), oprac. H. Barycz, indeks osób oprac. K. Targosz, Wrocław-Warszawa-Kraków-Gdańsk 1971.

Dziennik podróży po cudzych krajach odbytej w latach 1660-1663, wyd. Ł. Tatomir, „Biblioteka Ossolińskich. Poczet Nowy" 1864, t. 5, s. 303-397.

Gawarecki S., Diariusz drogi. Podróż Jana i Marka Sobieskich po Europie 1646-1648, oprac. M. Kunicki-Goldfinger, Warszawa 2013.

H.J. Černín na cestě za Alpy a Pyreneje, I: Cestovní denník Heřmana Jakuba Černína z let 1678-1682, eds. Z. Hojda, E. Chodějovska, M. Hajná, Al. Tesařikova, Praha 2014.

Informacya JM Panu Stanisławowi Rzewuskiemu starościcowi chetmskiemu, jadacemu do cudzych krajów, od JM Pana Jabłonowskiego, hetmana wielkiego koronnego, „,Tygodnik Ilustrowany" 1864, t. 9, nr 232.

Jasia Ługowskiego podróże do szkół w cudzych krajach 1639-1643, oprac. K. Muszyńska, Warszawa 1974.

Lepiecki F., Secunda vota secunda omnia lextissimis neosponsis [...] Georgio Lubomirski [...] et [...] Barbarae de Sczekarzowice Tartoviae [...], Cracoviae [1655].

Markiewicz A., Instrukcja hetmana Stanisława Jabłonowskiego do synów Jana Stanisława i Aleksandra Jana z 1682 r. [w:] Spoleczeństwo a rodzina, Spoleczeństwo Staropolskie. Seria Nowa, t. III, red. A. Karpiński, Warszawa 2011.

Die Matrikel der Deutschen Nation in Siena (1573-1738), ed. F. Weigle, t. I, Tübingen 1962. Peregrynacja Stanistawa Wierzbowskiego wojewodzica sieradzkiego do Francji w latach 1678, 1679, 1680 i 1681, wyd. J.K. Załuski, „Czas” (dodatek miesięczny) 1858 (marzec), t. IX.

Potocki W., Ogród fraszek, t. I, wyd. A. Brückner, Lwów 1907. 
[Radoliński W.], Pamiętnik podróży odbytej roku 1661-1663 po Austryi, Włoszech i Francyi, wyd. Z. C[elichowski], Torun 1874.

Rudzki J.S., Isagoge politica, seu magnanimae iuventutis Polonae introductio, ad rempublicam liberam: in qua ostenditur cunctis Regium iter ad honores capessendos, et rite obeunda munera publica [...], Cracoviae 1665.

Wierowski W., Caelatura phoebi in armis gentilitiis nobilissimae et antiquissimae Toporum familiae editi [...] Sigismundi Tarto [...] sub tempus hymenaeo sacrum, quo cum [...] Elisabetha Kostczanka [...] sacrum nuptiarum inibat, Cracoviae [1636].

\section{Opracowania}

Barycz H., Historia Szkół Nowodworskich, Kraków 1988.

Barycz H., Z dziejów polskich wędrówek naukowych za granice,, Wrocław 1969.

Białek E., Mrozowicz W., Polonische Einträge in den Stammbüchern der Universitätsbibliothek Wrockaw, „Acta Universitatis Wratislaviensis” 1985, t. 891, s. 111-132; 1986, t. 954, s. 327-330.

Black J., The British Abroad. The Grand Tour in the Eighteenth Century, London 2003.

Black J., France and the Grand Tour, New York 2003.

Black J., Italy and the Grand Tour, New Haven-London 2003.

Bodniak S., Album amicorum Jana Zborowskiego, „Silva Rerum” 1927, n. 11-12, s. 174 179.

Boutier J., Le Grand Tour des gentilshommes et les académies d'éducation pour la noblesse : France et Italie, XVI - XVIII ${ }^{e}$ siècle [w:] Grand Tour. Adeliges Reisen und Europaische Kultur vom 14. bis 18. Jahrhundert. Akten der Internationalen Kolloquien in der villa Vigoni 1999 und im Deutschen Historischen Institut Paris 2000, hrsg. von R. Babel, W. Paravicini, Ostfildern 2005, s. 237-253.

Bratuń M., ,, Ten wykwintny, wykształcony Europejczyk”. Zagraniczne studia i podróże edukacyjne Michała Jerzego Wandalina Mniszcha w latach 1762-1768, Opole 2002.

Chachaj M., Jeszcze o wykształceniu Tarłów od połowy V do połowy XVII wieku [w:] Tartowie. Z dziejów kulturalnych, gospodarczych i politycznych rodu, t. 2, red. H. Gmiterek, A. Szymanek, Janowiec nad Wisłą 2009, s. 33-35.

Chachaj M., Metryki zagranicznych uniwersytetów i akademii jako źródło do dziejów kultury polskiej (XVI-XVII w.) [w:] Studia z dziejów epoki renesansu, red. H. Zins, Warszawa 1979, s. 37-56.

Chachaj M., Wyksztatcenie Tartów od połowy XV do połowy XVII wieku [w:] Tartowie. Rola $i$ znaczenie rodziny $w$ dziejach ogólnonarodowych i lokalnych XVI-XIX wieku. Materiaty sesji naukowej 24 czerwca 2006, red. H. Gmiterek, A. Szymanek, Janowiec nad Wisłą 2006 [2007], s. 52-71.

Chachaj M., Wykształcenie Tarłów od połowy XVII do końca XVIII wieku [w:] Tarłowie. $Z$ dziejów kulturalnych, gospodarczych i politycznych rodu, t. 2, red. H. Gmiterek, A. Szymanek, Janowiec nad Wisłą 2009, s. 9-31.

Chachaj M., Zagraniczna edukacja Radziwiłtów od początku XVI do połowy XVII wieku, Lublin 1995.

Chachaj M., Związki kulturalne Sieny i Polski do końca XVIII wieku. Staropolscy studenci i podróżnicy w Sienie. Sieneńczycy i ich dzieła w Polsce, Lublin 1998. 
Chaney E., The Evolution of the Grand Tour: Anglo-Italian Cultural Relations since the Renaissance, London 2002.

Chaney E., The Grand Tour and the Great Rebellion: Richard Lassels and "The Voyage of Italy" in the 17 Century, Geneve 1985.

Chaney E., Wilks T., The Jacobean Grand Tour: Early Stuart Travellers in Europe, London-New York 2014.

Chmiel A., ,Imionnik” z 1582 r. Jana Alembeka aptekarza, „Nowe Czasopismo Aptekarskie" 1920, s. 4-12.

Chodějovská E., I giovani nobili provenienti dalle Terre ceche nel loto viaggio d'educazione a Roma. Topografia della loro vita quotidiana nella Città eterna del XVII secolo, „Bolletino dell'Istituto storico ceco di Roma" 2012, bolletino 8.

Czapliński W., Długosz J., Podróż młodego magnata do szkół, Warszawa 1969.

Długosz J., Ossoliński Maksymilian, PSB, t. 24, Wrocław-Kraków 1979, s. 423-424.

Fijakowski A., Tradycja i nowatorstwo w Orbis sensualium pictus Jana Amosa Komeńskiego, Warszawa 2012.

Fokt K., Rudzki (Rucki) Jan Stanisław [w:] K. Ożóg, K. Fokt, M. Mikuła, M. Zdanek, D. Wójcik-Zega, K. Kuras, Profesorowie Wydziału Prawa Uniwersytetu Jagiellońskiego, t. I: 1364-1780, red. W. Uruszczak, Kraków 2015.

Frejlichówna J., Ideat wychowawczy szlachty polskiej w XVI i początku XVII wieku, Warszawa 1938.

Golik-Prus A., Dedykacje z Alba Amicorum przełomu wieków XVI i XVII w zbiorach Biblioteki Jagiellońskiej jako źródło biograficzne, „Biuletyn Biblioteki Jagiellońskiej”, R. 49, 1999, s. 137-141.

Golik-Prus A., Kobiece wpisy sztambuchowe w Polsce XVI-XVII wieku, „Biuletyn Biblioteki Jagiellońskiej”, R. 48, 1998, s. 13-21.

Golik-Prus A., Poezja figuratywna na kartach sztambuchów z przełomu wieku XVI i XVII, „Odrodzenie i Reformacja w Polsce” 2000, t. 44, s. 101-106.

Golik-Prus A., Różnorodność formuły „,non omnis moriar” w tacińskich wpisach sztambuchowych przełomu XVI i XVII w., Katowice 2004.

Golik-Prus A., Wpisy Daniela Naborowskiego do „, alba amicorum ”, „Pamiętnik Literacki” 1997, z. 4, s. 145-151.

Hibbert Ch., The Grand Tour, London 1969.

Kamecka M., Do cudzych krajów. Edukacyjne podróże szlachty polskiej do Francji w epoce saskiej, Białystok 2012.

Kot S., Historia wychowania, t. I, Warszawa 1994.

Kot S., Polacy na studiach w Orleanie w XVI i XVII wieku, „Sprawozdania z Czynności i Posiedzeń Polskiej Akademii Umiejętności” 1920, nr 5, s. 2-3.

Kotarski E., O imionnikach XVI i XVII wieku [w:] Staropolska kultura rękopisu, red. H. Dziechcińska, Warszawa 1990, s. 93-111.

Kotońska K., Album przyjaciót Jana Naeranusa, „Odrodzenie i Reformacja w Polsce” 1990, t. 34, s. 169-206.

Kubeš J., Náročne dospiváni urozených. Kavalirské cesty české a rakouské šlechty (1620 1750), Pelhřimov 2013.

Kucharski A., Theatrum peregrinandi. Poznawcze aspekty staropolskich podróży w epoce późnego baroku, Toruń 2013.

Lasocki Z., Cetner Jan, PSB, t. 3, Kraków 1937, s. 239-240.

Leibetseder M., Die Kavalierstour. Adlige Erziehungreisen im 17. und 18. Jahrhundert, Köln 2004. 
Markiewicz A., „In limine cizího světa“. Jak se v Praze vzdělávala šlechta z polsko-litevského soustátí v posledni čtvrtině 17. století, „Acta Universitatis Carolinae. Historia Universitatis Carolinae Pragensis. Příspevky k dějinám Univerzity Karlovy” 2016, t. 56, fasc. 2 [w druku].

Markiewicz A., Peregrinationes Jablonovianae. Grand tour w czasach Jana III Sobieskiego, Warszawa 2011.

Mączak A., Życie codzienne w podróżach po Europie w XVI i XVII wieku, Warszawa 1980.

Mead W.E., The Grand Tour in the Eighteenth Century, Boston 1914.

Nowaczyk K., Hafty w sztambuchach Biblioteki Uniwersyteckiej w Poznaniu, „Biblioteka” 2011, 15/24, s. 281-294.

The Origins of the Grand Tour. The Travels of Robert Montagu, Lord Mandeville (16491654), William Hammond (1655-1658), and Banaster Maynard (1660-1663), ed. M.G. Brennan, London 2004.

Pawlak M., Studia uniwersyteckie młodzieży z Prus Królewskich w XVI-XVIII wieku, Toruń 1988.

Pelc J., Stowo i obraz. Na pograniczu literatury i sztuk plastycznych, Kraków 2002.

Pietrzyk Z., Przyczynek do studiów zagranicznych Mikołaja Ostroroga i Jakuba Sobieskiego, „Odrodzenie i Reformacja w Polsce” 1998, t. 42, s. 139-144.

Pietrzyk Z., Sztambuchy jako źródło do peregrynacji studenckich na przykładzie Polaków studiujacych w Strasburgu, „Odrodzenie i Reformacja w Polsce” 1999, t. 43, s. 139-150.

Pietrzyk Z., W kręgu Strasburga. Z peregrynacji młodzieży z Rzeczpospolitej polsko-litewskiej w latach 1538-1621, Kraków 1997.

Pirożyńska C., Sztambuch Daniela Naborowskiego, „Biuletyn Biblioteki Jagiellońskiej”, R. 21, 1971, s. 93-104.

Piwarski Z., Chomętowski Marcin, PSB, t. 3, Kraków 1937.

Popiołek B., Podróże edukacyjne i poznawcze w źródłach czasów saskich [w:] Polski Grand Tour w XVIII i początkach XIX wieku, red. A. Roćko, Warszawa 2014, s. 45-64.

Przyboś K., Myszkowski Franciszek, PSB, t. 22, Wrocław-Kraków 1977, s. 370.

Rachuba A., Sapieha Benedykt Pawet, PSB, t. 34, Wrocław-Warszawa 1992-1993, s. 583 591

Rachuba A., Sapieha Franciszek Stefan, PSB, t. 34, Wrocław-Warszawa 1992-1993, s. 602-604.

Rachuba A., Sapieha Kazimierz Jan Pawet, PSB, t. 35, Warszawa-Kraków 1994, s. 37-48.

Rastawiecki E., Imionnik cudzoziemców A. Kazanowskiego, „Biblioteka Warszawska” 1853, t. 50, s. 441-479.

Rok B., Życie towarzyskie Teofili z Radziwitłów Morawskiej w europejskiej podróży w latach 1773-1774 [w:] Władza i prestiz. Magnateria Rzeczypospolitej w XVI-XVIII wieku, red. J. Urwanowicz, Białystok 2003, s. 639-649.

Sweet R., Cities and the Grand Tour. The British in Italy, c. 1690-1820, Cambridge 2012.

Targosz K., Jana Sobieskiego nauki i peregrynacje, Wrocław 1985.

Trease L.G., The Grand Tour, London 1967.

Tygielski W., Na cóż te koszta i trudy? W jakim celu $w$ XVII wieku wysyłano młodzież szlachecka na zagraniczne studia?, „Odrodzenie i Reformacja w Polsce” 2006, t. 50, s. 141-156.

Urzędnicy centralni i nadworni Polski XIV-XVIII wieku. Spisy, oprac. K. Chłapowski, S. Ciara, Ł. Kądziela, T. Nowakowski, E. Opaliński, G. Rutkowska, T. Zielińska, red. A. Gąsiorowski, Kórnik 1992. 
Urzędnicy Wielkiego Księstwa Litewskiego. Spisy, t. 4: Ziemia smoleńska i województwo smoleńskie XIV-XVIII wieku, red. A. Rachuba, oprac. H. Lulewicz, A. Rachuba, P.P. Romaniuk, Warszawa 2003.

Urzędnicy województwa lubelskiego XVI-XVIII wieku. Spisy, oprac. W. Kłaczewski, W. Urban, red. A. Gąsiorowski, Kórnik 1991.

Urzędnicy województwa ruskiego XIV-XVIII wieku (ziemie halicka, lwowska, przemyska, sanocka). Spisy, oprac. K. Przyboś, Wrocław-Warszawa-Kraków-Gdańsk-Łódź 1987.

Urzędnicy województwa sandomierskiego XVI-XVIII wieku. Spisy, oprac. K. Chłapowski, A. Falniowska-Gradowska, red. A. Gąsiorowski, Kórnik 1993.

Wrześniak M., Florencja - Muzeum. Miasto i jego sztuka w oczach polskich podróżników, Kraków 2013.

Zelenková P., “Vidi stellas undecim”. Šternberské alegorie na grafických listech podle Karla Škréty, „Umění” 2006, t. 54, s. 327-342.

Ziembiński J., Manu propria. Wpis Olbrychta Karmanowskiego do Liber amicorum Andrzeja Lubienieckiego, „Odrodzenie i Reformacja w Polsce” 2013, t. 57, s. 154-169.

Żołądź-Strzelczyk D., Peregrinatio academica. Studia młodzieży polskiej z Korony i Litwy na akademiach i uniwersytetach niemieckich $w$ XVI i pierwszej połowie XVII wieku, Poznań 1996. 